\title{
Elementary EFL Students' Errors: How Does the Teacher Correct Students' Errors?
}

\author{
Baiq Raudatul Jannah ${ }^{1}$, Furaidah ${ }^{1}$, Sri Rachmajanti ${ }^{1}$ \\ ${ }^{1}$ Pendidikan Bahasa Inggris-Universitas Negeri Malang
}

\begin{tabular}{l} 
ARTICLE INFO \\
\hline Article History: \\
Received : 27-09-2019 \\
Approved: 15-04-2020 \\
\hline
\end{tabular}

Key Words:

elementary efl students; corrective feedback;

\author{
Correspondence Address: \\ Baiq Raudatul Jannah \\ Pendidikan Bahasa Inggris \\ Universitas Negeri Malang \\ Jalan Semarang 5 Malang \\ E-mail: jannahleneng.2013@gmail.com
}

\begin{abstract}
Abstract: Teacher's corrective feedback on in English class has been studied many times in secondary or higher education level. However, how a teacher deliver corrective feedback in non-English subjects for students in elementary students rarely become the focus of studies. Therefore, this qualitative research studied the elementary students of International Class Program of SD Laboratorium UM. The second grader and the teachers contributed as the research subjects. There were five corrective feedback types used by the teacher, translation, first language, conversational recast, clarification, and explicit. Those feedbacks were considered as effective feedbacks since the students mostly responded to it.
\end{abstract}

\begin{abstract}
Abstrak: Penelitian tentang feedback korektif guru seringkali diteliti di pendidikan menengah atau di tingkat perguruan tinggi. Namun, bagaimana guru menyampaikan feedback korektif untuk siswa sekolah dasar pada pelajaran non-bahasa Inggris sangat jarang dijadikan fokus penelitian. Maka dari itu, penelitian ini mengkaji bagaimana guru memberikan korektiffeedback pada siswa Program Kelas Internasional SD Laboratorium UM. Siswa kelas dua beserta gurunya menjadi subjek penelitian ini. Ada lima jenis feedback korektif yang diberikan guru, yaitu translation, first language, conversational recast, clarification, dan explicit. Feedback tersebut direspons oleh siswa.
\end{abstract}

Acquiring first language is different from learning a language as a second language. Firstly, it differs in language resources. L1 resources comes from the nearest-native person living with children with the language-using environment, while foreign or second language resources are non-native speakers and the environment of a foreign language learning is not strongly supportive for children as the communication is rarely conveyed in the target language. What these conditions talk about are that first language is acquired by children as a means of daily communication and interaction, in other word, children acquire their first language resulting in native language competence (Saville-Troike, 2006), while a target language is learned as a subject in a school. It is a common fact that a target language is only used by students and teachers only in the classroom. Additionally, it is hard to bring real situation of a language to learning site when language is learned as a foreign language. Consequently, it is hard for children to acquire the language since they are not surrounded by the real situation of how to use that language.

Since the students are non-native English speakers, making errors becomes a common phenomenon found in the English learning class. An error as a defective part of learners' writing or speaking (Coyle, Hood \& Marsh, 2010). An error is a signature of the learning process that cannot be avoided, yet it does not need to be worried about. The teachers or parents who witness the process of language learning will realize that children cannot expand their language competence without making errors. As said by Lightbown and Spada (1999) an error generated by a language learner, either in speaking or writing, proves that they have developed the interlanguage system. Then, this is the step of learning to reach a higher level of competence indicating that they have learned something.

One of the teacher's roles in the classroom is that a teacher is responsible for language input provider. Therefore, corrective feedbacks, when students produce wrong utterances, from a teacher is essentially needed. Without giving feedbacks, it will be harder for students to notice whether they have done right or there is something needed to be improved. A survey involving students at Arts and Letters Faculty of Santo Thomas University conducted by Alamis (2010) proved that most of the students believe that reading the teacher's revision enhances their writing skills as the teacher's comments of their writing will show their strong and weak points. Furthermore, the teacher's correction will help them to clarify their understanding of what they have learned. 
Corrective feedback, however, is not absolutely viewed as an essential act that must be delivered by the teacher when errors take place. As said before, an error is a natural phenomenon in the process of acquiring the language. Krashen (2003) argues that the teacher, for language learning, does not necessarily revise all of the students' error. Lightbown and Spada (1999) propose that the learner should not be expected to adopt the corrective feedback provided by the teacher immediately and constantly. The error correction will help the learning in some particular conditions or when the learners are ready to absorb the feedback.

It is worth to consider what Bartram and Walton (1999) argue about the non-native speaker teacher related to correction. They argue that a non-native speaker teacher should be highly careful in judging a particular form of language is wrong because everybody's knowledge of a language is partial. What the non-native teachers consider wrong might be correct for others. It might be a part of the language that a teacher thinks that it does not exist, but in fact, it does exist.

For error correction in speaking, Harmer (2002) reminds the teacher to not interrupt students when they are in the middle of their speaking, even if they produce wrongness in their grammar, lexical, or pronunciation. Interrupting students in mid-flow will disturb students' concentration and will drag students' confidence. Consequently, this will highly cause them to hesitate to speak. A finding of a study reveals that students want to be corrected when they make an error because it is hard for them to notice their mistakes. However, they do not want the teacher to interrupt them when they are speaking to point out their wrongness (Kavaliauskienè and Anusiené, 2012).

There are six types of verbal interaction error proposed by Lyster and Ranta (1997) the use of first language, gender, grammatical, phonological, lexical, and multiple. From these six categories of errors, the gender will not be taken into account in classifying the errors, since this study focuses only on the language aspects. An English utterance combining with first language is considered as first language error. Grammatical error refers to inability of students in conforming their utterance to the English Grammar Standard. It can be a misplaced modifier, inappropriate verb tense, or other grammatical incorrectness. Lexical error can be detected when a learner inappropriately use a certain word in the utterance. This error occur in the choice of word. Phonological error is indeed about pronunciation. A learner pronounce an utterance which is phonologically incorrect. An utterance produced by a learner contains more than one error. As an example, it combines both lexical and grammatical error in one sentence.

Bartram and Walton (1999) divide correction into three; self-correction, teacher-correction, and peer-correction. Selfcorrection is a correction done by students themselves, peer-correction is a correction given by student's friends in the classroom, while teacher-correction is a correction provided by a teacher. A teacher-correction seems to be more effective since a teacher is still the most powerful one for students in the classroom.

There are six types of corrective feedback: explicit correction, recast, clarification request, metalinguistic feedback, elicitation, and repetition Lyster and Ranta (1997). Explicit correction is when the teacher clearly notices the students' error, tells that their utterances are incorrect, and immediately provides the correct feedback. This is one of the corrective feedbacks that a teacher frequently uses to revise the students' error. As studied by Gitsaki and Altobaiti (2010), the two teachers, teaching students with an intermediate and beginner level of English proficiency at private English school in Australia, frequently notice the error right after the students produce an error and offer a direct revision of that erroneous.

Recast is a kind of implicit corrective feedback. The teacher will not directly notice the student's error, yet the teacher still provides the correct form explicitly without giving more information about the erroneous utterance. Bartram and Walton (1999) define recast corrective feedback as repeating in context. The teacher will just repeat the error part only.

A study conducted by Surakka (2007) about corrective feedback and learner's uptake in elementary school found that this corrective feedback was mostly used by the teacher to revise the students' error. About $34.7 \%$ of the corrective feedback was recast. Safari (2013) in his research also discovered recast was most preferred by the teachers to offer feedback to learners' error. More than $50 \%$ of erroneous utterances were corrected through recast. Here is an example of recast corrective feedback found by Surakka (2007) in the fourth grader.

Clarification request is shown by indicating that there is an error in student's utterance which causes the utterance is not understandable. Lyster and Ranta (1997) define clarification as a way to give an indication to students that their utterance has been misunderstood by the teacher and then clarification is required. The teacher may express the indication by saying "excuse me?" or "pardon". After that, the learners will reformulate their utterance in the correct sentence. This type of correction is explained by Bartram and Walton (1999) as pretend to misunderstand.

Metalinguistic Feedback is done by giving an indication that a student makes an error. Metalinguistic feedback contains question, information, or comment which will trigger students' well-formed utterance. The teacher will not explicitly provide the correct form, but the teacher may ask students by saying “can you find your error?". Since metalinguistic feedback is implicit feedback requiring higher order thinking of students to find their own mistake, this type of correction is rarely used by the teacher for revising students' error. As studied by Suryoputro and Amaliah (2016), metalinguistic feedback was the last two preferable feedbacks, only $4.5 \%$ of the correction was delivered through metalinguistic feedback.

Elicitation is direct corrective feedback without expressing the right one, but the students will perform self-correction. The teacher obtains the correct form of student's utterance by signing that they have made an error without producing the right one, giving a pause in the sentence, and then letting the students complete the utterance. As an example: "no, not that. It is a... ?". 
Repetition is like explicit feedback. However, it does not directly give the correct form to the learner. The lecturer will repeat the student's utterance and put the intonation to highlight the error, or the teacher just repeat the ill-form part of the student's utterance and in doing so, the learner hopefully understands the error part and naturally is able to establish self-correction. In the same study of Suryoputro and Amilah (2016), repetition was the least-used corrective feedback. As the teacher does not explicitly provide the right form of students' erroneous, the students must think harder to guess the right form of their error.

Correcting student's error does not always impact positively. Corrective feedback provided by a teacher may not be appropriate with the students' English proficiency level which leads students to not responding as the teacher's feedback appropriately. It may result in a bad effect on students' learning motivation if the teacher delivers feedback which is not suitable with students' preference. A survey conducted by Alamis (2010) evidenced that the teacher's feedback does not always fit the students' preference. Although the study shows that teacher's revision improves students' writing skills, the students prefer to be commented on their writing content rather than form. Mahdy and Saadany (2013) also studied the oral feedback in the EFL classroom. They found that students prefer explicit corrective feedback rather than the other corrective feedback, although this type of corrective feedback is the least useful for students' improvement.

Timing takes an essential role in feedback strategy. The purpose of giving corrective feedback, either it is given immediately or slightly delayed, is the students know what should be corrected and then perform the correct one. Bookhart (2008) says that the feedback should be given while the student is still mindful of the topic. It should come when the students are still thinking of the learning goal as a learning goal. As a result, the students are able to process the feedback and they know what the correct one is. Park (2010), his study about teachers' and students' preference on corrective feedback suggest correcting students' error when they have finished their sentence which is believed by the participants of study as the most effective time for correction and such a way of correction will enhance students' speaking accuracy and fluency.

The amount of feedback that should be provided might be the hardest one for the teacher. The teacher should realize what students have already known and then the teacher can consider the amount of feedback that will upgrade students' competence. The teacher should be able to judge the appropriate amount of feedback needed by students so that they will understand what they should do then. So, a not overwhelming number of feedbacks given the right timing will be good feedbacks for students.

Feedback is commonly related to the production of errors by students. However, praising feedback is an exception. Feedback is not limited to correcting errors, while it may appear in the form of praising. This is a part of feedback proposed by Dunlay, Burt \& Krashen (1982) called as positive feedback. Praising feedback appear when students perform correct communication in the target language then the teacher may give positive feedback to students' performance by saying "good job". Hidayanti (2015) who studied teacher's feedback in questioning activity proved that praising student's work leads to students' understanding that they are in the right track when answering the teacher's question. Additionally, when it is supported by adding motivated words, it stimulate the learners to elaborate their answer with a more complete sentence.

The implementation of English as one of the subjects taught in the primary level attracts the researcher to conduct a study on this level since most of the previous research, related to corrective feedback and students' responses towards the teacher's correction, is done in higher education level. Suryoputro (2016) studies students majoring in English education in Universitas Muhammadiyah Prof. Dr. Hamka. Park (2010) also selects 51 college students of different universities for the subjects of his research. Another research conducted by Fadilah (2016) also studies the students at the university level. These are some studies showing that mostly the research studies students from higher education level as the concern of the research. Then, it means how students react to their teacher's corrective feedback need to be studied at primary level.

English education research also mostly takes only English subject class as the setting of the research. Arudina (2017) takes English subject class only. Zhao (2009) studies the students of primary school, however, the class chosen as the setting of her research is English subject class only. Then, this research aims to fill the gap of the research site that is going to be studied. This research is going to study the students when they are in the English subject class and non-English subjects. Therefore, the school selected as the research site is the school that applies a class program where non-English subjects are also taught in English.

\section{METHOD}

This research was descriptive qualitative research which aimed to study what errors were produced by the students in their speaking and reading aloud activities. This research also studied how the teachers provided verbal feedback for the errors. International Class Program of SD Laboratorium UM was chosen as the research site. The second-grader consisting of 27 students which were 17 girls and 10 boys. The teachers also contributed as the research subjects in this study. Four subjects, Art, English, Mathematics, and Science which applied English as medium of instruction were observed.

\section{RESULT}

\section{Teachers' Corrective Feedback}

All of students' errors got corrected by the teacher except for the use first language. The use of first language almost never got corrections from the teacher. It has been treated by giving other responses, it was responded by giving direct answer that students expected. 
Table 1. Teachers' Corrective Feedback

\begin{tabular}{cccccccc}
\hline No. & Types of Error & \multicolumn{6}{c}{ Teachers } \\
\hline & & Cr & L1c & CR & Ex & Cl & Total \\
\hline 1. & L1 (27) & 1 & - & - & - & - & 1 \\
2. & PE (15) & - & 1 & 7 & - & 6 & 14 \\
3. & LE (3) & & 1 & 1 & 1 & 1 & 3 \\
4. & GE (2) & & 1 & & & & 2 \\
\hline \multicolumn{1}{r}{} \\
\hline
\end{tabular}

Although Lyster and Ranta's theory (1997) of corrective feedback was used as the main guidelines for the researcher in this study, the final results discovered that teachers' corrective feedbacks did not entirely match those feedback types. Metalinguistic was the only teacher' response that was in line with it. Those five corrective feedbacks used by the teachers found in this research were conversational recast, clarification, metalinguistic, translation, and first language.

Previous types of corrective feedbacks (Lyster \& Ranta, 1997) was then upgraded into the newest version (Lyster, Saito, \& Sato, 2013) which was conversational recast (CR), one of those latest types, matched the corrective feedback found in this research. Unlike recast which was defined as correcting the ill part of students' error. Conversational recast (CR) was done by reformulating the student's mistake in order to resolve miscommunication which is usually followed by confirmation checking. This was used by the teachers when correcting students' errors in reading aloud activity.

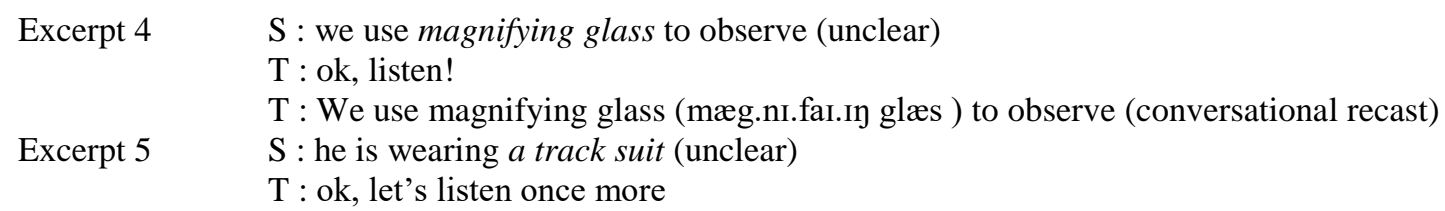

The use of first language errors was once corrected by the teacher by translating the student's utterance. Translation (TR) as a corrective feedback was not stated by Lyster and Ranta (1997), however, the finding showed that the teacher translated student' utterance spoken in first language into the target language.

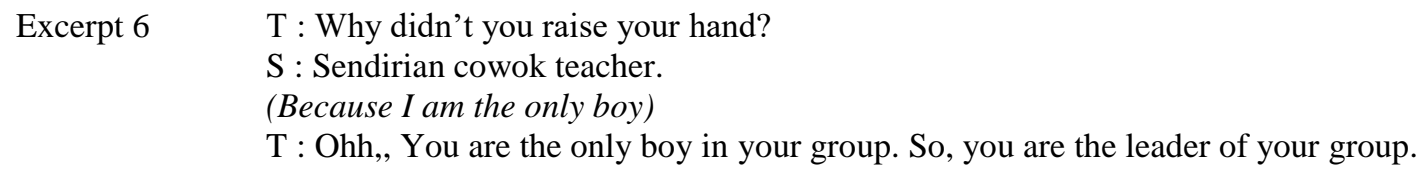

First Language Corrective Feedback (L1c) was used by the teacher when correcting students' grammatical, lexical, and phonological errors. It was like explicit feedback but delivered in student's first language.

Excerpt $7 \quad \mathrm{~S}:$ Quite far the train station.

$\mathrm{T}:$ Jangan lupa "from"

Clarification $(\mathbf{C l})$ feedback in this research is different from clarification proposed by Lyster and Ranta (1997). They defined clarification feedback by expressing the indication by saying "excuse me?" or "pardon". After that, the learners will repeat their utterance in the correct sentence. This type of correction is explained by Bartram and Walton (1999) as pretend to misunderstand. Clarification, differently, in this finding meant revising the error by questioning the students followed by giving choices, the correct form and restating the ill form of student's utterance. It was like multiple choices for students, in which they had to choose the correct form from those choices.

Excerpt $8 \mathrm{~S}$ : The car is behind the van (phonological error)

$\mathrm{T}$ : Behind or bi' hīnd (Clarification)

Excerpt $9 \quad \mathrm{~S}:$ The cat is sitting in at the car

T : Pilih salah satu "in" atau "at"

Explicit corrective feedback was once used to repair student's utterance spoken in grammar. Explicit was the only one corrective feedback corresponding to Lyster and Ranta (1997) where the teacher provided information for students what error they had made, yet the teacher did not state the exact correct form.

Excerpt 10S: the bus in front of the van

T: don't forget "is"

$\mathrm{S}$ : the bus is in front of the van 


\section{DISCUSSION \\ Corrective Feedback}

From those errors, some of the errors were corrected and some were not corrected by the teacher. Related to the teacher's corrective feedback, this current research revealed that the teachers' corrections were needed by the learners. The teachers believed that they have to give correction when students make an error in their language performances. This result was in line with the previous research which studied teacher's perspective about corrective feedback (Muhsin, 2016, Kirgoz \& Agcam, 2015). In this current research, the teacher thought that teachers' correction was required when the students performed an error. Then, corrective feedback should not be seen as a harmful act, he students, moreover, performed positive acts by responding to those feedback with the revised one.

Phonological error which occurred during reading aloud activity after listening to an audio was corrected this error by giving conversational feedback. This feedback is conducted by giving an opportunity to students to relisten to the audio (Lyster, Saito, \& Sato, 2013). The teacher did not clearly state the error made by students, however the students were able to correct their errors after relistening to the audio.

The teacher used clarification corrective feedback for students' phonological and lexical errors. Clarification corrective feedback in this study is different from what Lyster and Ranta (1997) define as clarification feedback. Clarification corrective feedback in this research was performed by giving choices for students to choose the right correction for their errors. So, instead of telling the direct correction clearly, the teacher decided to give choices for students. This kind of correction will attract students' engagement in learning. Teacher' corrective feedback should provide an opportunity for students to engage in learning activity to enable students to perform self-correction (Lam, Yang, Salter \& Carless, 2011).

If Lyster and Ranta (1997) defined explicit correction as clearly pointing out the students' error and providing correction, then, the findings of this research revealed that the teacher almost never explicitly told their students that they had made erroneous. Instead, the teacher reacted to students' errors by providing the corrections without noticing the error. This finding was contradictory with another research which found that the teacher preferred explicit corrective feedback in providing correction (Maolida, 2013). The teacher argued that in this lower level of primary students, it was not the right time to expose students' mistakes explicitly which will lead to downgrading students' confidence to express their language skill. What the students need was the correction of their mistake without telling them a further explanation of their mistake.

As said previously, some of the errors were not getting any correction from the teachers. The teacher directly answer the questions in English which was understandable for students since they have been taught those English words and it was unrelated to content or topic they were learning. However, in term of errors and corrective feedback, the use of first language in this circumstance should be corrected because the students' utterances were sentences that they usually say in their classroom activity. Those utterances were repeatedly spoken by students. Therefore, teacher, at least, should exemplify the English of those utterances and asked them to repeat it. Then, hopefully, the students would not continuously repeat the same utterances in their first language. Especially for math and art and design subjects, where in these classes they were mostly required to do written task rather than verbal task. The students' conversation with their teacher was mostly manifested in question form, then the teacher responded those question by giving the answers of their question without telling them what they should say if they want to ask those question in English.

Responding in by continuing communication in English done when the students' utterances were demonstrated in question form. Differently, when the students spoke In Indonesian which was related to content, the teacher responded their students' utterance speaking in Indonesia by repeating the students' sentence in Indonesia. This condition was where the translation feedback was needed. When the error might be caused by the result of low proficiency level of students then translation is needed to enrich students' language input (Panova \& Lyster, 2002). Translation could be assumed as a necessity for students' utterance in their first language as a result of students' low proficiency level (Panova \& Lyster, 2002). Considering the low proficiency of students which caused them speaking in Indonesian, using first language can substitute the target language as an initial language for instruction because the learners should understand what they are going to learn, then they can understand.

Despite some errors were not corrected by the teacher, the teacher strategically had done the right way to react to their students' errors which resulted in students' reactions. In term of the time of delivering errors, the teacher did not directly correct the error, instead they delayed delivering corrective feedback, waited and let the students finish what they wanted to say. Yet they were still mindful about the topic. As said by Bookhart (2008), corrective feedbacks should come when the students are still thinking of the learning goal to enable students to process the feedback. Park (2010) also found that delivering corrective feedback after students finished their utterance as the most effective time to give a correction. Interrupting students lead to provoking anxiety and discouraging students to show their language performance. Delayed feedback was the best time for oral corrective feedback, rather than interrupting students or post-delayed corrective feedback (Ölmezer-Öztürk \& Öztürk, 2016).

The implementation of CLIL in this school could not be perfect as it had to be. CLIL, as defined by Coyle et al, (2010), is an approach of a dual-focused education coming as an innovative fusion of both content and language. However, L1 was still frequently used as a language instruction because the teacher's main target was to ensure the students comprehend the materials. yet they still tried their best to use English as their initial language instruction. The use of target language for teaching instruction in CLIL setting especially for primary education level is complex. On one side, the maximal exposure of second language enriches students' input and boosts their confidence to practice the language. On the other hand, it could be harmful if the learners failed 
to comprehend the content because of the low proficiency of target language which will lessen their classroom participation. This two sides require teachers' ability in managing the use of both L1 and target language (Kiely, 2011). L1 should not be seen as prohibited language as the use of code-switching deepened students' understanding and attracted students' engagement and participation (Madriñan, 2014).

The use of first language as language instruction also was caused by the teachers' background, which they did not come with English language education background. Teaching experience was also an influential factor affecting the success of CLIL implementation. Therefore, teacher training is necessary in order to improve teaching practice and adjust it to CLIL core principles (Campillo, Sánchez, \& Miralles, 2019). SD Laboratorium UM has applied a program to support the teachers' skill in using English for their teaching language. The school started a program where the teacher had to speak English in front of their fellow teachers. This kind of program was expected to boost teachers' ability and confidence in using English as their instruction language.

\section{CONCLUSION}

The teachers, generally, corrected all the errors except for the use of first language. The way the teachers corrected those errors were different from the Lyster and Ranta (1997). The teacher corrected their errors by conversational recast, asking for clarification, translating to the target language, metalinguistic and using students' first language. The teachers were able to deliver corrective feedback in appropriate way, in the right time, and with the right amount of feedback that students need. As a result, those feedback were generally responded by students with no repair needed.

The use of first language, especially for content subjects, was still undeniable. However, the teachers should be appreciated for their effort to deliver the content using English as initial language instruction since they came to the class with no English background education.

Practically, the teacher, especially those who are teaching in immersion or CLIL class where the teacher are required to teach in English in their language instruction, should pay attention to their students speaking in their first language. The teacher should emphasize on students utterance which are repeatedly spoken in students' first language, which also those utterances has been taught by their teacher. Then, the teacher should present corrective feedbacks for students in that circumstance.

For those who are interested to conduct studies in this field, the researcher suggest to start the study in the early day of semester. This research was conducted in the last time of active schedule and in the second semester which tends to have more days off, when during this time did not run as effective as it was expected. The next study should also extend the observations until data redundancy can be reached.

\section{REFERENCES}

Alamis, M. M. P. (2010). Evaluating Students' Reactions and Responses to Teachers' Written Feedbacks. Philippine ESL Journal, Vol. 5, July

Barkley, E. F. 2010. Student Engagement Technique: A Handbook for College Faculty. United State of America: Jossey-Bass.

Campillo, J. M., Sánchez, R., \& Miralles, P. (2019). Primary Teachers' Perceptions of CLIL Implementation in Spain. English Language Teaching, 12(4), 149. https://doi.org/10.5539/elt.v12n4p149

Creswell, J. W. (2012). Educational Research: Planning, Conducting, and Evaluating Quantitative and Qualitative Research. University of Nebraska-Lincoln: Pearson Education Inc.

Dunlay, H., Burt, M., \& Krashen, S. (1982). Language Two. Oxford: Oxford University Press.

Ellis, R. (2005). Instructed Second Language Acquisition, A Literature Review: Report to the Ministry of Education. Ministry of Education.

Fadilah, A. E. (2016). EFL Students' Preferences for Corrective Feedback in Speaking Class. Unpublished Thesis. Universitas Negeri Malang, Malang.

Gitshaki, C., \& Althobaiti, N. (2010). ESL Teachers' Use of Corrective Feedback and Its Effect on Learners' Uptake. The Journal of Asia TEFL, 7(1), 197-219.

Hidayanti, W. R. (2015). Teacher's and Students' Questioning and Teacher's Feedback in EFL Classroom. Unpublished Thesis. Universitas Negeri Malang, Malang.

Kavaliauskienè, G., \& Anusienè, L. (2012). Case Study: Learner Attitudes Towards the Correction of Mistakes. Socialinés Technologijos Social Technologies, 2(1), 88-101.

Kirgoz, Y., \& Agcam, R. (2015). Teachers' Perceptions on Corrective Feedback in Turkish Primary Schools. Procedia - Social and Behavioral Sciences, 192, 574-581. https://doi.org/10.1016/j.sbspro.2015.06.096

Lyster, R., \& Ranta, L. (1997). Corrective Feedback and Learner Uptake: Negotiation of Form in Communicative

Classrooms. Studies in Second Language Acquisition, 19(1), 37-66 doi:10.1017/S0272263197001034

Lyster, R., Saito, K., \& Sato, M. (2013). Language Teaching. https://doi.org/10.1017/S0261444812000365

Madriñan, M. S. (2014). The Use of First Language in the Second-Language Classroom: A Support for Second Language Acquisition. Gist Education and Learning Research Journal, 9(9), 50-66.

Mahdi, D., \& Saadany, N. E. (2013). Oral Feedback in the EFL Classroom. Unpublished Thesis. Malmo University.

Maolida, E. H. (2013). A Descriptive Study of Teacher's Oral Feedback In an ESL Young Learner Classroom in Indonesia. $K @ T a, 15(2), 117-123$. https://doi.org/10.9744/kata.15.2.117-124 
Mason, J. (2002). Qualitative Researching: Second Edition. London: Sage Publication.

Mendez, E. H., \& Cruz, M. R. R. (2012). Teachers' Perceptions about Oral Corrective Feedback and Their Practice in EFL Classrooms. National University of Colombia.

Muhsin, A. (2016). The Effectiveness of Positive Feedback in Teaching Speaking Skill. Lingua Cultura, $10(1), 25$. https://doi.org/10.21512/lc.v10i1.873

Panova, I., \& Lyster, R. (2002). Patterns of Corrective Feedback and Uptake in an Adult ESL Classroom. TESOL Quarterly, $36(4), 573$.

Park, H. S. (2010). Teachers' and Learners' Preferences for Error Correction. Unpublished Thesis. California State University.

Ramirez Verdugo, M. D. (2011). CLIL Varieties Across Europe. In Guidelines for CLIL Implementation in Primary and PrePrimary Education.

Rifqi, M. S. (2016). EFL Teachers' Belief about Spoken Corrective Feedback and Their Classroom Practice. Unpublished Thesis. Universitas Negeri Malang, Malang.

Safari, P. (2013). A Descriptive Study on Corrective Feedback and Learners' Uptake during Interactions in a Communicative EFL Class. Theory and Practice in Language Studies, 3(7), 1165-1175.

Surakka, K. (2007). Corrective Feedback and Learner Uptake in an EFL Classroom. Unpublished Thesis. University of Jyväskylä.

Suryoputro, G., \& Amaliah, A. (2016). EFL Students' Responses on Oral Corrective Feedbacks and Uptakes in Speaking Class. International Journal of Language and Linguistics, 3(5).

Yin, R. K. (2011). Qualitative Research from Start to Finish. United State of America: The Guilford Press. 